\title{
Pemanfaatan Limbah Ekstraksi Indigofera tinctoria L. sebagai Pupuk Organik pada Usaha Batik Pewarna Alami di Sukoharjo
}

\author{
Maria Theresia Sri Budiastuti ${ }^{1 *}$, Bambang Pujiasmanto ${ }^{1}$, Trijono Djoko Sulistyo ${ }^{1}$, Aprilia Ike \\ Nurmalasari $^{1}$, Desy Setyaningrum ${ }^{2}$ \\ ${ }^{1}$ Program Studi Agroteknologi, Fakultas Pertanian, Universitas Sebelas Maret, Surakarta \\ ${ }^{2}$ Program Magister Agronomi, Fakultas Pertanian, Universitas Sebelas Maret, Surakarta \\ *Correspoding Author : mariatheresia@staff.uns.ac.id
}

\begin{abstract}
ABSTRAK
Kegiatan pengabdian masyarakat bekerjasama dengan CV. Indigo Biru Baru yang merupakan usaha batik pewarna alami di Desa Puron, Kecamatan Bulu, Kabupaten Sukoharjo dengan memanfaatkan tanaman Indigofera tinctoria sebagai pewarna biru alami. Pengelolaan tanaman tersebut sebagai pewarna alami menghasilkan limbah yang belum dimanfaatkan. Permasalahan limbah tersebut mendorong pemanfaatan limbah sebagai pupuk organik padat. Tujuan kegiatan pengabdian yaitu membina mitra dalam pengelolaan limbah ekstraksi sebagai pupuk organik. Metode yang diterapkan yaitu: uji coba pembuatan pupuk organic Limbah Ekstraksi Indigofera tinctoria, analisis kualitas pupuk organik, penyuluhan dan demonstrasi tentang Pemanfaatan Limbah Sebagai Pupuk Organik, Demontrasi plot budidaya Indigofera tinctoria dengan aplikasi pupuk organik, Demontrasi plot budidaya sayuran dengan aplikasi pupuk organik. Hasil kegiatan pengabdian masyarakat menunjukkan bahwa limbah ekstraksi Indigofera tinctoria dapat digunakan sebagai pupuk organik dan memenuhi pesyaratan standar sebagai pupuk organik menurut Permentan No.70/ Permentan/SR.140/10/2011. Kualitas pupuk organic meliputi parameter kadar air, $\mathrm{N}$ total, $\mathrm{P}_{2} \mathrm{O}_{5}, \mathrm{~K}_{2} \mathrm{O}, \mathrm{C}$-organik, $\mathrm{C} / \mathrm{N}$ rasio dan $\mathrm{pH}$ menjadi indikator keberhasilan pengelolaan limbah sebagai pupuk organik. Berdasarkan kegiatan penyuluhan menunjukkan bahwa peserta interaktif dan berminat untuk memanfaatan limbah ekstraksi Indigofera tinctoria sebagai pupuk organik. Pupuk organik limbah ekstraksi dapat digunakan sebagai media tanam untuk penanaman sayuran dan pembibitan Indigofera tinctoria. Hasil percobaan menunjukkan bahwa pemberian pupuk organik limbah ekstraksi dapat meningkatkan pertumbuhan tanaman Indigofera tinctoria pada 6 MST. Hasil kegiatan yang diperoleh yaitu peningkatan pengetahuan mengenai teknologi tepat guna untuk memanfaatkan limbah.
\end{abstract}

Kata Kunci: Indigofera tinctoria L., Limbah Organik, Pewarna Alami, Pupuk Organik.

\section{ABSTRACT}

Community service activities in collaboration with CV. Indigo Biru Baru, which is a natural dye batik business in Puron Village, Bulu District, Sukoharjo Regency by utilizing Indigofera tinctoria as natural blue dye. The management of these plants as natural dyes produces waste that has not been utilized. The waste problem encourages the use of waste as organic fertilizer. The purpose of the community service activity is to develop partners in the management of extraction waste as organic fertilizer. The methods applied were: trial of making organic fertilizers from Indigofera tinctoria extraction waste, analysis of the quality of organic fertilizers, counseling and demonstrations on waste utilization as organic fertilizer, demonstration of Indigofera tinctoria cultivation plots with organic fertilizer applications, demonstration of vegetable cultivation plots with organic fertilizer applications. The results of community service activities show that Indigofera tinctoria extraction waste can be used as organic fertilizer and meets the standard requirements as organic fertilizer according to Permentan No.70 / Permentan / SR.140 / 10/2011. The quality of organic fertilizers includes parameters of moisture content, total N, P2O5, K2O, $\mathrm{C}$-organic, $\mathrm{C} / \mathrm{N}$ ratio and $\mathrm{pH}$ as indicators of the success of waste management as organic fertilizer. Based on the extension activity, it shows that the participants are interactive and interested in utilizing Indigofera tinctoria extraction waste as organic fertilizer. Extracted waste organic fertilizer can be used as a growing medium for vegetable cultivation and Indigofera tinctoria nursery. The results showed that the application of organic waste extraction fertilizer could increase the growth of Indigofera tinctoria at 6 WAP. The results of the activities obtained were increased knowledge about appropriate technology for utilizing waste.

Keywords: Indigofera tinctoria L., Organik Waste, Natural Dyes, Organik Fertilizers. 


\section{PENDAHULUAN}

Kegiatan pengabdian masyarakat bekerjasama dengan CV. Indigo Biru Baru yang merupakan usaha batik pewarna alami di Desa Puron, Kecamatan Bulu, Kabupaten Sukoharjo. Usaha tersebut memanfaatkan tanaman Indigofera tinctoria sebagai pewarna biru alami. Kegiatan produksi CV Indigo Biru sejak tahun 2016 dengan produksi berupa pasta, ekstrak cair, serbuk indigo dan berbagai batik pewarna alami dari tanaman Indigofera tinctoria dan telah dipasarkan di Jawa Tengah, Jakarta, Bali, Jawa Timur, Kalimantan, Malaysia, dan Jepang. Keberadaan CV. Indigo Biru Baru juga telah mengaktifkan kembali berbagai klaster batik tulis, cap, dan lurik di wilayah Sukoharjo, Sragen, dan Klaten. Kapasitas produksi pewarna alami di CV Indigo Biru saat ini telah mencapai 1.500 kilogram pasta per bulan.

Indigofera tinctoria merupakan merupakan salah satu spesies leguminaceae (Motamarri et al., 2012) dan sebagai sumber warna biru karena mengandung metabolit sekunder yaitu indigo (Hariri et al., 2017). Pengelolaan tanaman tersebut sebagai pewarna alami menghasilkan limbah sebesar 90\% dan pewarna alami hanya 10\% (Sihta et al., 2018). Ketersediaan limbah ekstraksi pewarna alami Indigofera tinctoria di CV. Indigo Biru Baru cukup banyak (Gambar 1). Limbah tersebut belum dimanfatakan oleh CV. Indigo Biru Baru maupun petani. Penanganan limbah hanya dibuang di sepanjang jalan sawah kemudian dibakar (Gambar 2). Permasalahan limbah tersebut mendorong pemanfaatan limbah sebagai pupuk organik. Hal ini disebabkan karena limbah dari ekstraksi pewarna alami merupakan limbah organik. Limbah ekstraksi tersebut dapat dimanfaatkan sebagai biogas karena mengandung $\mathrm{N}, \mathrm{CH}_{4}, \mathrm{NH}_{3}, \mathrm{CO}_{2}, \mathrm{O}_{2}$ (Ridwan et al., 2019). Namun, informasi mengenai pemanfaatan limbah ekstraksi menjadi pupuk organik belum diketahui, sehingga diperlukan inovasi pupuk organik dengan bahan dasar limbah ekstraksi.

Pengelolaan limbah organik sebagai pupuk organik diketahui dapat memperbaiki sifat fisika-kimia tanah dalam jangka panjang dengan meningkatkan kandungan bahan organik dan $\mathrm{pH}$ tanah, mengandung nutrisi essensial untuk tanaman, dan memberikan manfaat ekonomi dan lingkungan dalam hal pengelolaan limbah (Laurent et al., 2020). Pengomposan limbah hijau merupakan salah satu upaya meningkatkan nilai produk yang bersifat ramah lingkungan dan berdampak positif terhadap tanah dan tanaman. Beberapa penelitian telah melaporkan pengelolaan limbah menjadi pupuk organik sebagai sumber nutrisi dalam pertanian seperti limbah industri dengan campuran kotoran ayam, serbuk gergaji dan sampah hijau (Ravindran et al., 2019; Harouns et al., 2007). Limbah organik seperti olahan tebu dalam produksi bioethanol (vinasse) telah dimanfaatkan sebagai pupuk organik dengan menggunakan metode fermentasi aerobik. Pupuk tersebut mengandung unsur $\mathrm{N}, \mathrm{P}$ dan $\mathrm{K}$ dan telah diterapkan untuk meningkatkan pertumbuhan tomat (Kusumaningtyas et al., 2016).

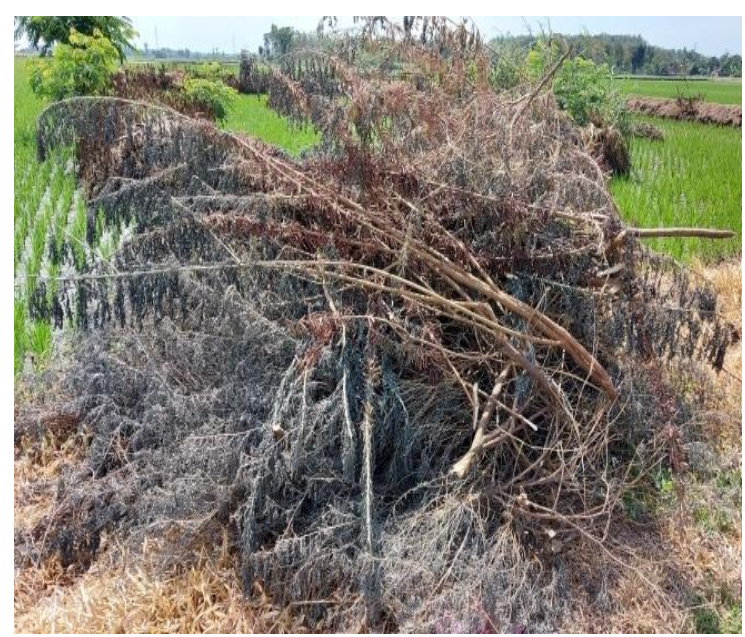

Gambar 1. Limbah ekstraksi pewarna alami Indigofera tinctoria

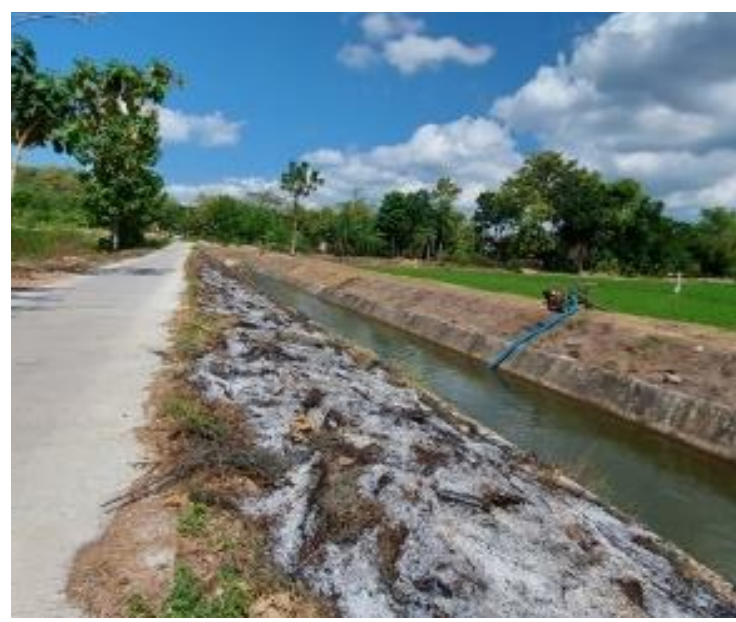

Gambar 2. Pengolahan Limbah ekstraksi pewarna alami Indigofera tinctoria

Bahan limbah merupakan salah satu faktor penentu kualitas produk pupuk organik. Indigofera tinctoria merupakan salah satu keluarga leguminaceae. Legum berperan penting pemenuhan nutrisi tanah dan tanaman (Sánchez- 
Chino et al., 2015). Legum dapat bersimbiosis dengan mikroba tanah seperti rhizobium (Elkoca, 2008), mikoriza (Grover et al., 2011). Pupuk organik dari seresah tanaman legum dapat meningkatkan mineralisasi nitrogen dalam tanah, mempertahankan kelimpahan nematoda pada lahan kering, memperkuat ketahanan jaring makanan dalam tanah (Ney et al., 2020). Pupuk organik menjadi produk kaya nutrisi, aktif secara mikrobiologis mengandung zat pengatur tumbuh seperti hormon untuk pertumbuhan dan hasil tanaman (Mupambwa et al., 2017). Pupuk organik digunakan untuk mengurangi pupuk kimia, karena penggunaan pupuk kimia secara terus menerus menyebabkan penurunan kesuburan tanah dan pencemaran lingkungan pada tanah semakin tinggi (Alori et al., 2017). Tujuan kegiatan pengabdian masyarakat yaitu membina mitra dalam pengelolaan limbah ekstraksi Indigofera tinctoria sebagai pupuk organik. Pupuk organik limbah ekstraksi diharapkan dapat menjadi salah satu bahan pemupukan oleh petani setempat.

\section{BAHAN DAN METODE}

Metode yang diterapkan untuk merealisasikan tujuan pengabdian masyarakat untuk CV. Indigo Biru Baru dan petani di Desa Puron, Kecamatan Bulu, Kabupaten Sukoharjo berupa: uji coba pembuatan pupuk organik berbahan dasar limbah ekstraksi Indigofera tinctoria, analisis kualitas pupuk organik, penyuluhan dan demonstrasi pembuatan pupuk organik, demontrasi plot budidaya Indigofera tinctoria dengan aplikasi pupuk organik, demontrasi plot budidaya sayuran dengan aplikasi pupuk organik.

Solusi yang ditawarkan untuk mengatasi permasalaahan utama yang dihadapi mitra (1) adalah teknologi pengolahan limbah ekstraksi sebagai pupuk organik, selanjutnya (2) pupuk organik tersebut dapat digunakan sebagai pupuk bagi usaha pembibitan oleh CV. Indigo Biru Baru, (3) sebagai pupuk organik maupun campuran media tanam untuk petani di Desa Puron. Partisipasi mitra dalam pelaksanaan program pengabdian masyarakat sebagai berikut:

1) Menyediakan limbah ekstraksi

2) Menyediakan sumberdaya manusia sebagai subyek pada berbagai kegiatan
Uji coba pembuatan pupuk organik dari limbah ekstraksi Indigofera tinctoria

Tim pengabdian telah melakukan uji pendahuluan dalam pembuatan pupuk organik dari limbah ekstraksi (Gambar 3). Kegiatan dilaksanakan di Rumah Kompos yang telah dibangun oleh tim pengabdian (Gambar 4). Rumah kompos dibangun di Depan CV. Indigo Biru Baru dengan ukuran 3 × $3 \mathrm{~m}$. Di dalam rumah kompos terdapat mesin pencacah, tong, bahan-bahan untuk pembuatan pupuk organik

Bahan untuk pembuatan pupuk organik antara lain $142 \mathrm{~kg}$ limbah kering ekstraksi Indigofera tinctoria, pupuk kandang sapi (perbandingan 1:10 $=14,2 \mathrm{~kg}$ pupuk kandang sapi : $142 \mathrm{~kg}$ limbah), dedak (perbandingan 1:60 $=2,377 \mathrm{~kg}$ dedak $: 142 \mathrm{~kg}$ limbah), molase $500 \mathrm{ml}(1: 3=500 \mathrm{ml}$ molase : $142 \mathrm{~kg}$ limbah), dan EM4 $500 \mathrm{ml}(1: 3=500 \mathrm{ml}$ EM4 : $142 \mathrm{~kg}$ limbah), dan air. Alat yang digunakan untuk pembuatan pupuk organik antara lain rumah kompos, timbangan, mesin pencacah, wadah pengomposan (tong), cetok, cangkul, sprayer, dan terpal, thermometer.

Proses pembuatan pupuk organik: (1) mempersiapkan alat dan bahan, (2) menjemur limbah ekstraksi selama 48 jam, (3) mencacah limbah ekstraksi, (4) menimbang semua bahan, (5) limbah hasil cacahan dicampur dengan pupuk kandang sapi, dedak, molase, dan EM4, (6) setelah tercampur, pupuk dimasukkan ke dalam wadah pengomposan dan ditutup menggunakan plastik yang telah dilubangi. Pupuk diaduk setiap 7 hari sekali selama 30 hari. Pengadukan pupuk dilakukan untuk mengontrol suhu.

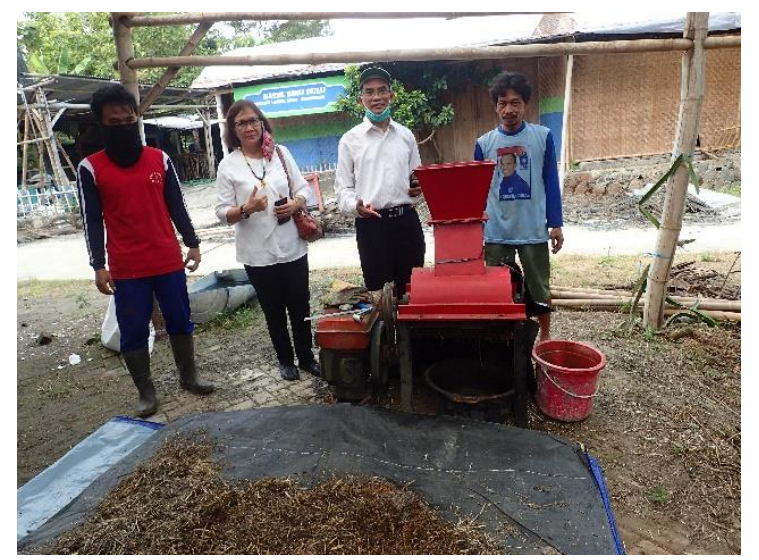

Gambar 3. Pengolahan Pupuk Organik oleh Tim Pengabdian 


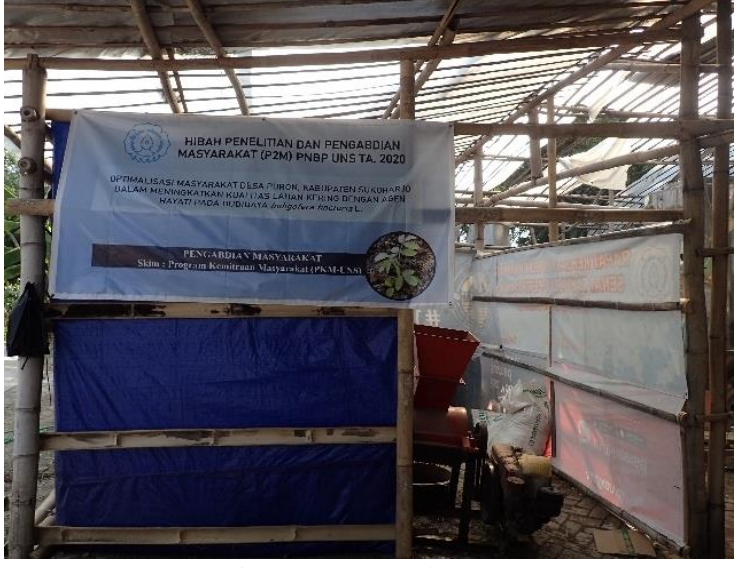

Gambar 4. Rumah Kompos

\section{Analisis Kualitas Pupuk Organik Limbah Ekstraksi Indigofera tinctoria}

Pupuk organik limbah ekstraksi Indigofera tinctoria dianalisis di Laboratorium Bioteknologi Lingkungan PT. Biodiversitas Bioteknologi Indonesia. Variabel yang dianalisis meliputi $\mathrm{N}$ total, $\mathrm{P}_{2} \mathrm{O}_{5}$ total, $\mathrm{K}_{2} \mathrm{O}$ total, $\mathrm{C}$ Organik, kadar air, $\mathrm{pH}, \mathrm{C} / \mathrm{N}$ ratio, warna dan suhu. Kualitas pupuk organik sebagai indikator keberhasilan kegiatan.

\section{Penyuluhan dan Demonstrasi Tentang Pemanfaatan Limbah Sebagai Pupuk Organik}

Kegiatan penyuluhan dilaksanakan di Aula Balai Desa Puron, Kecamatan Bulu, Kabupaten Sukoharjo. Penyuluhan dilaksanakan dengan menjelaskan mengenai manfaat limbah sebagai pupuk organik, bahan-bahan yang dapat digunakan sebagai pupuk organik, syarat pupuk organik menurut Permentan, proses pengelolaan limbah ekstraksi menjadi pupuk organik. Kegiatan penyuluhan mengundang direktur CV. Indigo Biru Baru beserta karyawan, perangkat Desa Puron, Bapak dan Ibu petani Desa Puron. Metode penyuluhan yang digunakan yaitu ceramah dengan menggunakan media cetak (hand out), elektronik (power point dan video) dan alat peraga seperti pupuk organik limbah ekstraksi. Demonstrasi dilakukan untuk meningkatkan keterampilan mitra dan petani dalam pengelolaan limbah.

\section{Demontrasi plot budidaya Indigofera tinctoria dengan aplikasi pupuk organik}

Pupuk organik limbah ekstraksi Indigofera tinctoria diaplikasikan pada tanaman Indigofera tinctoria sebagai demonstrasi plot. Demonstrasi plot berupa budidaya Indigofera tinctoria dengan perlakuan berbagai dosis pupuk organik yaitu: $0,50,100,150,200,250,300$, 350, 400, 450, $500 \mathrm{~g} /$ tanaman. Demontrasi tersebut dilaksanakan di lahan persawahan Desa Puron.

Demontrasi plot budidaya sayuran dengan aplikasi pupuk organik

Demontrasi plot berupa budidaya beberapa sayuran dengan menggunakan media tanam campuran antara pupuk organik dengan tanah (perbandingan 1:1). Sayuran yang dibudidayakan meliputi: cahai rawit, cabai besar, tomat, terong, pakcoy, kangkong, dan bayam. Demontrasi plot dilaksanakan di CV. Indigo Biru Baru.

\section{HASIL DAN PEMBAHASAN}

Uji Coba Pembuatan Pupuk Organik Limbah Ekstraksi Indigofera tinctoria

Limbah ekstraksi diolah menjadi pupuk organik dengan metode pengomposan secara anaerob (tanpa oksigen). Proses pengomposan disebut dekomposisi atau penguraian yang dapat terjadi secara anaerob (tanpa oksigen) maupun aerob (dengan oksigen), (Mardwita et al., 2019). Pengomposan limbah ekstraksi Indigofera tinctoria dengan menggunakan komposter dan Effective Microorganism 4 (EM4). EM4 digunakan untuk mempercepat proses pengomposan (Yuniwati et al., 2012).

Selama proses pengomposan terjadi pemanasan yaitu secara anaerob dan akan menyebabkan suhu mengarah ke thermofilic. Berdasarkan pengamatan bahwa suhu awal saat pengomposan limbah ekstraksi yaitu $45{ }^{\circ} \mathrm{C}$ dan suhu akhir saat pengomposan pada hari ke 30 adalah $29^{\circ} \mathrm{C}$. Suhu akan terus berubah selama proses pengomposan (Ekawandani \& Kusuma, 2018). Penelitian yang dilakukan oleh Ekawandani \& Kusuma, (2018) bahwa proses pengomposan pupuk organik dari sampah organik kulit pisang siap digunakan pada hari ke 20 dengan suhu akhir $27^{\circ} \mathrm{C}$. Hal tersebut disebabkan karena aktivitas mikroorganisme perombak memiliki suhu optimum sehingga suhu sebagai faktor yang mempengaruhi laju pengomposan,. Berdasarkan Purnomo et al., (2017) kemampuan hidup pada temperature mikroorganisme terbagi menjadi dua yaitu mikroorganisme mesofilik $\left(10{ }^{\circ} \mathrm{C}-45{ }^{\circ} \mathrm{C}\right)$ dan mikroorganisme termofilik $\left(45^{\circ} \mathrm{C}-65^{\circ} \mathrm{C}\right)$.

Pupuk organik dari limbah ekstraksi Indigofera tinctoria dapat digunakan setelah hari ke 30 proses pengomposan. Hal tersebut 
berdasarkan suhu dan karakteristik fisik pupuk organik. Suhu pupuk organik konstan pada hari ke-24 sampai hari ke-30 yaitu $29{ }^{\circ} \mathrm{C}$. Karakteristik fisik pupuk organik yaitu warna coklat kehitaman, berbau tanah, dan struktur remah karena masing-masing bahan pembentuk pupuk sudah tercampur. Perbedaan limbah organik dan pupuk organik yang telah matang terdapat pada Gambar 5.

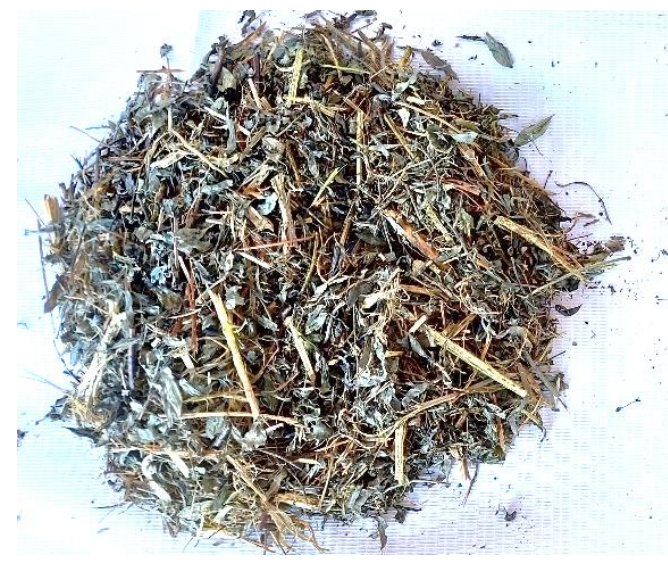

a. Limbah ekstraksi

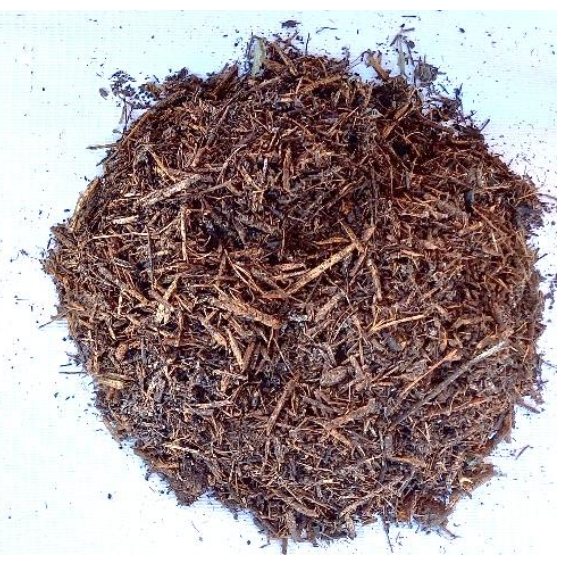

b. Pupuk organik

Gambar 5. Perbedaan limbah ekstraksi dan pupuk organik limbah ekstraksi Indigofera tinctoria

\section{Analisis Kualitas Pupuk Organik}

Pupuk organik siap digunakan setelah 1 bulan (Gambar 5b). Uji kualitas pupuk organic dari limbah ekstraksi Indigofera tinctoria dilakukan pada sampel pupuk organic yang telah dibuat dengan analisis laboratorium. Variabel yang dianalisis meliputi $\mathrm{N}$ total, $\mathrm{P}_{2} \mathrm{O}_{5}$ total, $\mathrm{K}_{2} \mathrm{O}$ total, C-Organik, kadar air, $\mathrm{pH}, \mathrm{C} / \mathrm{N}$ ratio, warna dan suhu. Ciri-ciri pupuk organik yang telah matang/stabil adalah berwarna gelap, berbau tanah, suhu konstan, dan memiliki kelembaban sekitar 60\% (Trivana et al., 2017). Berdasarkan hasil uji laboratorium menunjukkan bahwa pupuk organik dari limbah ekstraksi memenuhi standar Permentan No.70/ Permentan/SR.140/10/2011 tentang pupuk organik, pupuk hayati, dan pembenah tanah (Tabel 1).

Tabel 1. Hasil uji laboratorium pupuk organik limbah ekstraksi Indigofera tinctoria

\begin{tabular}{|c|c|c|c|c|c|}
\hline No & Parameter & Satuan & Hasil Pengujian & Standar $\left.{ }^{*}\right)$ & Keterangan \\
\hline 1. & Kadar air & $\%$ & 48.94 & $15-25$ & Memenuhi standar \\
\hline 2. & Temperature & ${ }^{\circ} \mathrm{C}$ & 29 & - & - \\
\hline 3. & Warna & - & $\begin{array}{l}\text { Coklat } \\
\text { kehitaman }\end{array}$ & - & - \\
\hline 4. & Bau & - & Berbau tanah & - & - \\
\hline 5. & $\mathrm{pH}$ & - & 9.22 & $4-9$ & Memenuhi standar \\
\hline 6. & C-Organik & $\%$ & 49.34 & Minimal 15 & Menenuhi standar \\
\hline 7. & $\mathrm{~N}$ total & & 3.26 & $\mathrm{~N}$ total $+\mathrm{P}_{2} \mathrm{O}_{5+}$ & Memenuhi standar \\
\hline 8. & Kadar $\mathrm{P}_{2} \mathrm{O}_{5}$ & $\%$ & 0.98 & $\mathrm{~K}_{2} \mathrm{O}$ minimal $4 \%$ & \\
\hline 9. & Kadar $\mathrm{K}_{2} \mathrm{O}$ & & 1.75 & & \\
\hline 10. & $\mathrm{C} / \mathrm{N}$ rasio & - & 15.6 & $15-25$ & Memenuhi standar \\
\hline
\end{tabular}

*)Standar menurut Departemen Pertanian Republik Indonesia (2011)

Tabel 1 menunjukkan hasil analisis sampel pupuk organik limbah ekstraksi Indigofera tinctoria. Jumlah $\mathrm{N}$ total $+\mathrm{P}_{2} \mathrm{O}_{5}+$ $\mathrm{K}_{2} \mathrm{O} 5,99 \%$ sudah memenuhi standar. Pupuk organik limbah ekstraksi mengandung Corganik sebesar $49.34 \%$ dengan kategori tinggi dan sudah memenuhi standar. C-Organik di tanah harus dipertahankan dan tidak kurang dari
2 persen, hal tersebut dimaksudkan supaya kandungan bahan organik tidak berkurang selama proses dekomposisi mineralisasi (Haq et al., 2014). Namun, berdasarkan Permentan nomor 70/Permentan/SR.140/10/2011 tentang pupuk organik, pupuk hayati dan pembenah tanah bahwa kandungan Organik minimal 6\%. C-organik tinggi akan meningkatkan populasi 
mikroorganisme di dalam tanah (Sukaryorini et al., 2016). Pupuk organik dengan kandungan COrganik tinggi akan berpengaruh terhadap peningkatan layanan siklus hara pada tanah ( $\mathrm{Li}$ et al., 2018). Pemberian pupuk organik meningkatkan $\mathrm{P}$ total, $\mathrm{pH}$, dan $\mathrm{C}$ organik dalam tanah. Akumulasi karbon dalam tanah merupakan fungsi dari hubungan antara input $\mathrm{C}$ dari pupuk organik, serta laju kerusakan $\mathrm{C}$ tanah (dekomposisi) yang dimediasi oleh mikroorganisme tanah dan lingkungan (jenis tanah, suhu) (Cooper et al., 2011).

Rasio $\mathrm{C} / \mathrm{N}$ merupakan perbandingan antara kandungan unsur karbon (C) dengan unsur nitrogen $(\mathrm{N})$ pada bahan organik. Rasio organik karbon dengan nitrogen $(\mathrm{C} / \mathrm{N}$ rasio) merupakan aspek terpenting dalam keseimbangan unsur hara total. Hal tersebut disebabkan karena aktivitas mikroorganisme membutuhkan karbon dan nitrogen. Berdasarkan hasil analisis bahwa pupuk organik limbah ekstraksi mengandung $\mathrm{C} / \mathrm{N}$ ratio sebesar 15,6 dan sudah memenuhi standar (Tabel 1). Aktivitas mikroorganisme berkurang pada $\mathrm{C} / \mathrm{N}$ rasio yang tinggi, sedangkan pada $\mathrm{C} / \mathrm{N}$ rasio yang terlalu rendah menyebabkan nitrogen tidak dapat diasimilasi oleh mikroorganisme dan akan hilang melalui volatisasi sebagai amoniak atau terdenitrifikasi (Purnomo et al., 2017).

Berdasarkan hasil analisis bahwa pupuk organik limbah ekstraksi Indigofera tinctoria memiliki pH 9,22 dan sudah memenuhi standar. Nilai $\mathrm{pH}$ selama proses pengomposan berpengaruh terhadap pertumbuhan mikroorganisme perombak. Nilai $\mathrm{pH}$ yang terlalu tinggi menyebabkan unsur nitrogen dalam bahan kompos berubah menjadi ammonia $\left(\mathrm{NH}_{3}\right)$. Sebaliknya, nilai $\mathrm{pH}$ yang terlalu rendah menyebabkan sebagian mikroorganisme perombak mati sehingga dapat mengganggu proses pengomposan. $\mathrm{pH}$ kompos mengalami kenaikan selama proses pengomposan karena terjadi penguraian protein dalam bahan organik dan pelepasan ammonia (Kurniawan et al., 2017).

\section{Penyuluhan dan Demonstrasi Tentang Pemanfaatan Limbah Sebagai Pupuk Organik}

Kegiatan penyuluhan "Pemanfaatan Limbah Ekstraksi Sebagai Pupuk Organik" telah dilaksanakan di Aula Balai Desa Puron, Kecamatan Bulu, Kabupaten Sukoharjo (Gambar 6). Kegiatan tersebut dihadiri oleh Direktur CV Indigo Biru Baru, Bapak sekretaris desa Puron, Karyawan CV. Indigo Biru Baru, Bapak dan Ibu Petani Desa Puron dengan jumlah peserta total 56 peserta (Gambar 7). Materi tentang manfaat pupuk organik, bahan-bahan yang dapat dimanfaatkan untuk pupuk organik, dan proses pembuatan pupuk organik disampaikan kepada peserta dalam kegiatan penyuluhan. Kegiatan demonstrasi atau pelatihan pembuatan pupuk dilakukan setelah pemaparan materi (Gambar 8). Peserta penyuluhan sangat interaktif dan berminat untuk memanfaatan limbah ekstraksi Indigofera tinctoria sebagai pupuk organik. Hasil kegiatan yang diperoleh yaitu peningkatan pengetahuan mengenai teknologi tepat guna untuk memanfaatkan limbah.

Penyampaian materi pertama yaitu tentang peran pupuk organik dalam mendukung pertanian berkelanjutan. Pertanian berkelanjutan adalah suatu bentuk pengelolaan lahan pertanian yang dapat menjamin kelestarian sumberdaya lahan (Sinukaban, 1999). Pertanian berkelanjutan membutuhkan fungsi dari tanah yang sehat (Moebius-Clune, 2017) dan Kesehatan tanah tidak terlepas dari masalah keberlanjutan (Doran dan Parkin 1996). Suatu upaya untuk mendukung pertanian berkelanjutan yaitu dengan pupuk organik. Penggunaan pupuk kimia secara terus-menerus memiliki dampak terhadap lingkungan, mikroba bermanfaat, hewan, dan juga manusia. Oleh karena itu, Pupuk organik sebagai teknologi pemupukan yang ramah lingkungan untuk mendukung pertanian berkelanjutan. Pupuk organik adalah bahan yang mengandung mikroorganisme seperti jamur, bakteri, dan protozoa yang memiliki kemampuan untuk meningkatkan kesuburan tanah dengan cara fiksasi nitrogen, pelarutan fosfor, dan penyerapan zat besi. Proses ini mengubah bentuk nutrisi yang tidak larut menjadi bentuk larut dan tersedia untuk akar tanaman (Amiri et al., 2017). Kegiatan penyuluhan ini mengupayakan pemahaman petani untuk mensubtitusi penggunaan pupuk kimia dengan pupuk organik.

Pupuk organik merupakan salah satu bahan yang sangat penting dalam upaya memperbaiki kesuburan dan kesehatan tanah (Gunawan et al., 2015). Penggunaan pupuk organik dalam jangka panjang dapat meningkatkan produktivitas lahan, mencegah degradasi lahan dan mampu meningkatkan kandungan humus di dalam tanah. Pupuk organik adalah pupuk yang berasal dari tumbuhan yaitu bahan tanaman segar atau kering 
hingga kotoran hewan dan serasah hingga produk sampingan pertanian (Green, 2015). Bahan pembuatan pupuk organik berpengaru terhadap kandungan nutrisi dari pupuk organik. Tim pengabdian menyampaikan bahan-bahan yang dapat dimanfaatkan untuk pembuatan pupuk yaitu limbah ekstraksi Indigofera tinctoria, jerami padi, eceng gondok, limbah rumah tangga, seresah daun maupun tulang ikan dan ayam. Limbah ekstraksi Indigofera tinctoria dapat digunakan sebagai pupuk organik karena merupakan limbah organik. Tanaman Indigofera tinctoria merupakan salah satu keluarga leguminaceae yang mampu memfiksasi $\mathrm{N}$ di atmosfer sehingga dapat meningkatkan ketersediaan nitrogen tanah (Kumar, 2020). Penggunaan tanaman legume sebagai pupuk meningkatkan mineralisasi bahan organik tanah dan aktivitas enzim tanah (Sánchez-Navarro et al., 2019).

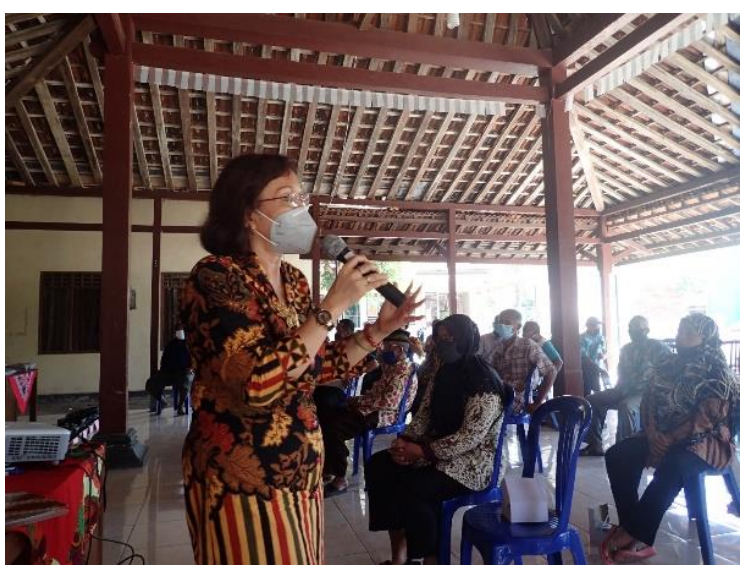

Gambar 6. Pemaparan materi oleh tim pengabdian

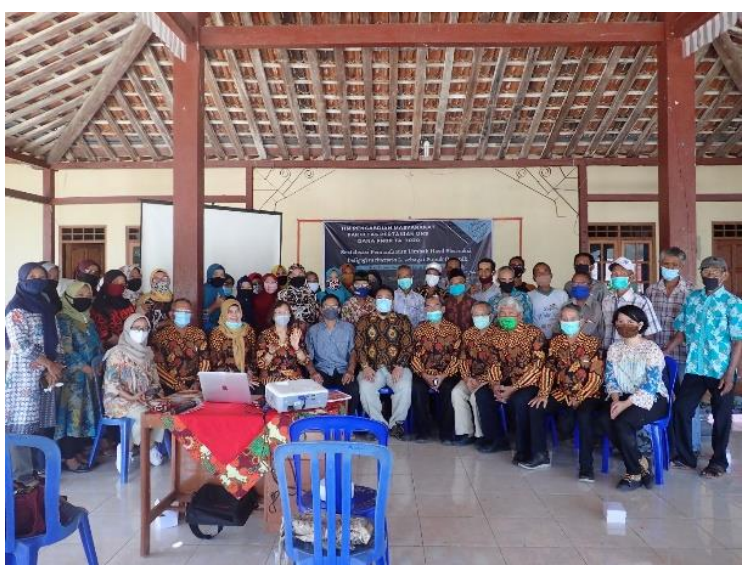

Gambar 7. Foto bersama kegiatan peyuluhan Demontrasi plot budidaya Indigofera tinctoria
dengan aplikasi pupuk organik

Demonstrasi plot dilakukan dengan tujuan untuk mengetahui respon tanaman Indigofera tinctoria terhadap pupuk organik limbah ekstraksi (Gambar 10). Percobaan dilakukan dengan beberapa dosis yaitu: 0, 50, 100, 150, 200, 250, 300, 350, 400, 450, 500 g/tanaman. Hasil percobaan menunjukkan bahwa pertumbuhan tanaman Indigofera tinctoria pada 6 MST lebih tinggi pada pengaplikasian pupuk organik limbah ekstraksi dibandingkan dengan tanpa pupuk limbah ekstraksi.

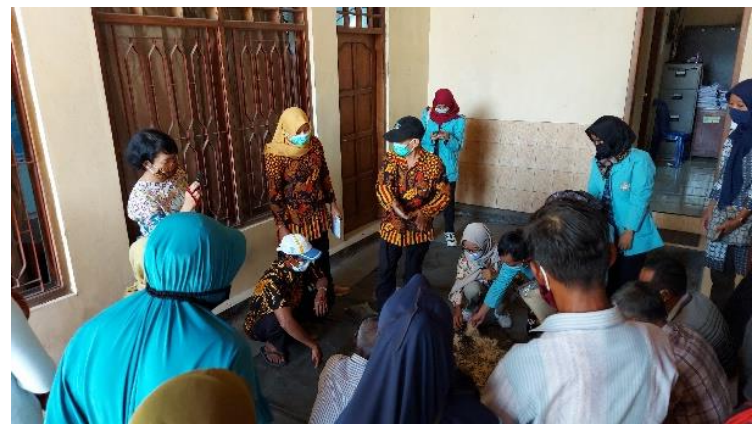

Gambar 8. Kegiatan demonstrasi pembuatan pupuk organik

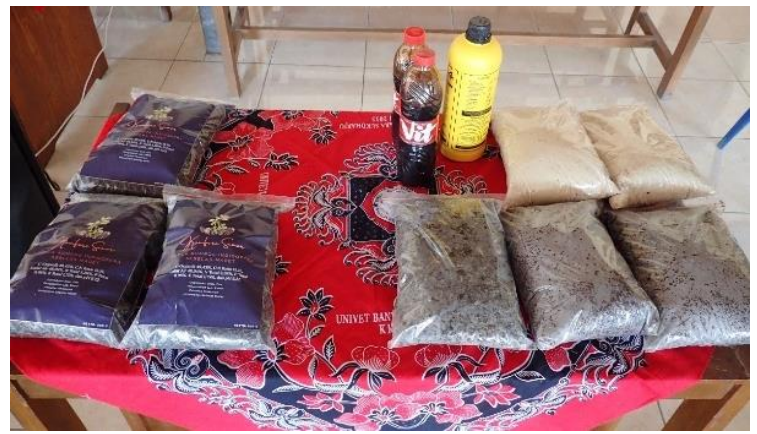

Gambar 9. Alat peraga kegiatan penyuluhan dan demonstrasi

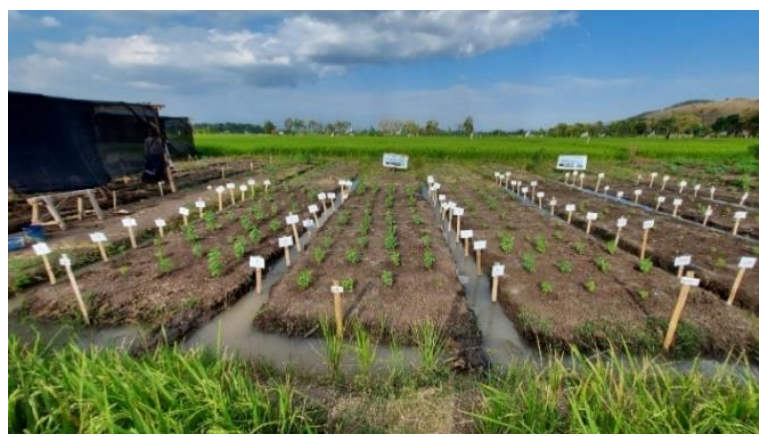

Gambar 10. Demontrasi plot budidaya Indigofera tinctoria dengan aplikasi pupuk organik

Berdasarkan Gambar 11 menunjukkan bahwa rata-rata tinggi tanaman, jumlah daun dan jumlah nodia pada dosis $0 \mathrm{~g} /$ tanaman hanya 18 $\mathrm{cm}, 26$ daun dan 3 nodia. Pemberian pupuk organik dengan dosis $50 \mathrm{~g} /$ tanaman sudah menunjukkan peningkatan pertumbuhan 
tanaman yaitu dengan tinggi $38 \mathrm{~cm}$, jumlah daun 38 dan jumlah nodia 10. Pertumbuhan tanaman semakin tinggi dengan dosis $500 \mathrm{~g} /$ tanaman yaitu dengan tinggi $75 \mathrm{~cm}$, jumlah daun 46 dan jumlah nodia 11. Peningkatan pertumbuhan di sebabkan karena pupuk organik limbah ekstraksi dapat memenuhi kebutuhan hara tanaman.
Berdasarkan hasil analisis (Tabel 1) menunjukkan bahwa kandungn C-organik pupuk tersebut tinggi. Kandungan karbon organik dari pupuk organik bisa sangat penting karena dapat mendorong peningkatan biomassa bakteri heterotrofik, dan mineralisasi nutrisi (Brust, 2019).

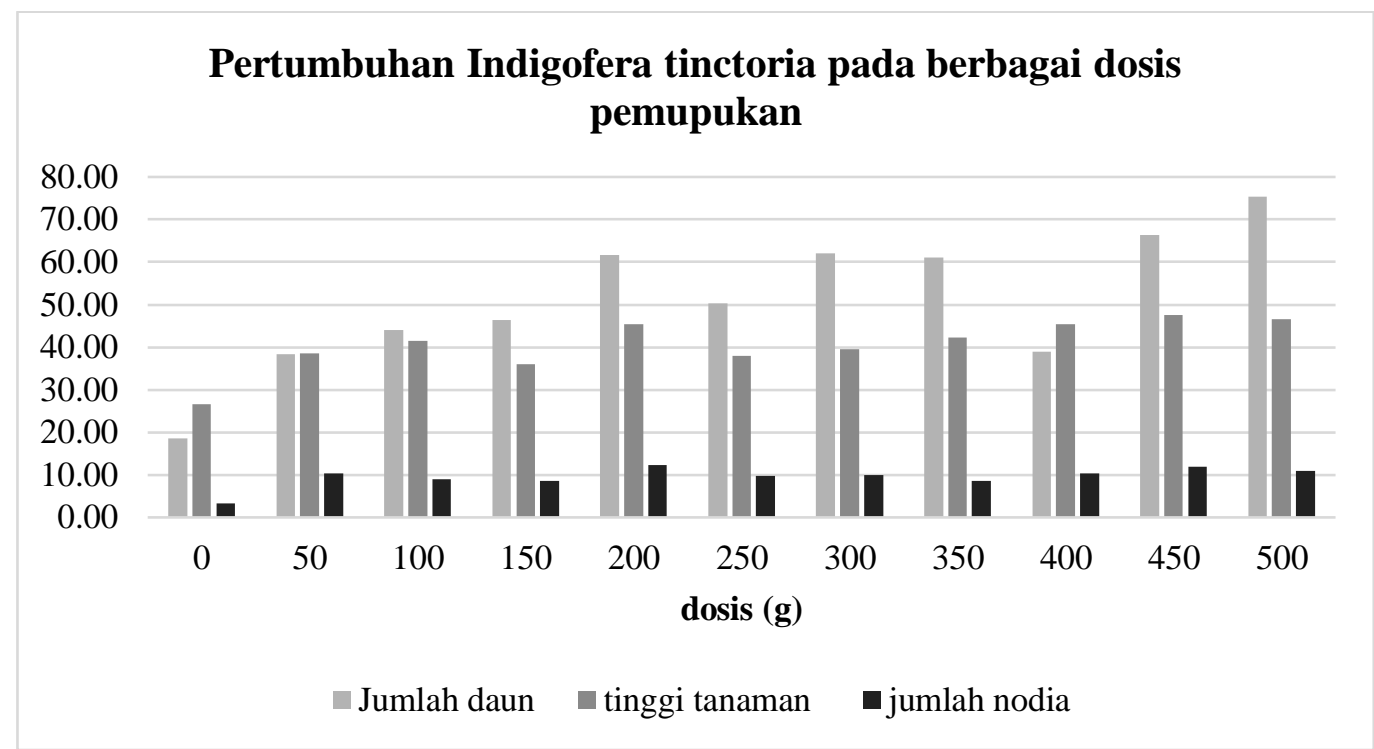

Gambar 11. Pertumbuhan tanaman Indigofera tinctoria 6 MST dengan pemberian pupuk organik limbah ekstraksi Indigofera tinctoria

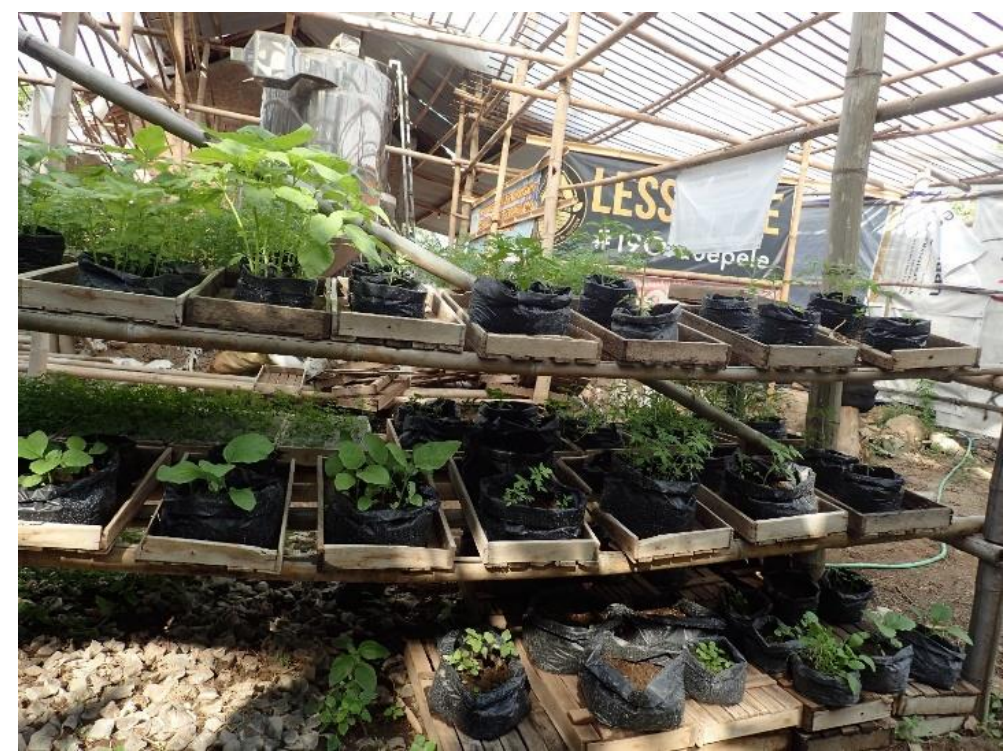

Gambar 12. Demonstrasi plot budidaya sayuran dengan media tanam tanah dan pupuk organik limbah ekstraksi Indigofera tinctoria (perbandingan 1:1)

Demontrasi plot budidaya sayuran dengan aplikasi pupuk organik

Demonstrasi plot budidaya sayuran dengan aplikasi pupuk organik bertujuan untuk mengertahui respon tanaman sayuran terhadap pupuk organik limbah ekstraksi. Pupuk organik limbah ekstraksi tersebut digunakan sebagai media tanam dalam penanaman sayuran. Sayuran yang digunakan yaitu: cabai rawit, cabai besar, terong, bayam, kangkung, tomat, dan pakcoy. Sayuran tersebut ditanam dengan menggunakan media tanam pupuk limbah ekstraksi dan tanah dengan perbandingan (1:1). Hasil pengamatan pada percobaan tersebut 
bahwa tanaman sayuran dapat tumbuh dengan baik (Gambar 12). Tanaman sayuran seperti bayam, kangkung dan pakcoy dapat tumbuh setelah 1 hari penanaman, sedangkan tanaman cabai rawit, cabai besar dan tomat dapat tumbuh setalah 4 hari penanaman.

\section{KESIMPULAN}

Limbah ekstraksi Indigofera tinctoria merupakan limbah organik yang dapat dimanfaatkan sebagai pupuk organik. Berdasarkan analisis kualitas pupuk organik menunjukkan bahwa pupuk organik mengandung jumlah $\mathrm{N}$ total, $\mathrm{P} 2 \mathrm{O} 5, \mathrm{~K} 2 \mathrm{O}, \mathrm{C} / \mathrm{N}$ rasio, $\mathrm{C}$ organik, kadar air, $\mathrm{pH}$ sudah memenuhi standar kualitas pupuk organic menurut Permentan No.70/ Permentan/SR.140/10/2011. Peserta penyuluhan sangat interaktif dan berminat untuk memanfaatan limbah ekstraksi Indigofera tinctoria sebagai pupuk organik. Hasil percobaan menunjukkan bahwa pemberian pupuk organik limbah ekstraksi dapat meningkatkan pertumbuhan tanaman Indigofera tinctoria pada 6 MST. Pupuk organik limbah ekstraksi dapat digunakan sebagai media tanam untuk penanaman sayuran dan pembibitan Indigofera tinctoria. Kegiatan pengabdian masyarakat mengatasi permasalahan mitra dalam pengelolaan limbah ekstraksi Indigofera tinctoria.

\section{UCAPAN TERIMA KASIH}

Tim pengabdian menyampaikan ucapan Terima Kasih Kepada Universitas Sebelas Maret yang telah mendanai Program Pengabdian ini melalui skim Program Kemitraan Masyarakat (PKM), Tahun anggaran 2020 dengan nomor kontrak 453/UN27.21/PN/2020.

\section{DAFTAR PUSTAKA}

Alori, E. T., Glick, B. R., \& Babalola, O. O. (2017). Microbial phosphorus solubilization and its potential for use in sustainable agriculture. Frontiers in Microbiology, 8(JUN), $1-8$. https://doi.org/10.3389/fmicb.2017.00971

Amiri, A., Kafi, M., Kalate-Jari, S., \& Matinizadeh, M. (2017). Morphology and responses of Tulipa gesneriana L. to light quality in combination with GA and cold storage time. Indian Journal of Agricultural Research, 51(6), 568-573.
https://doi.org/10.18805/IJARe.A-280

Brust, G. E. (2019). Management strategies for organik vegetable fertility. In Safety and Practice for Organik Food. Elsevier Inc. https://doi.org/10.1016/B978-0-12812060-6.00009-X

Cooper, J. M., Burton, D., Daniell, T. J., Griffiths, B. S., \& Zebarth, B. J. (2011). Carbon mineralization kinetics and soil biological characteristics as influenced by manure addition in soil incubated at a range of temperatures. European Journal of Soil Biology, 47(6), 392-399. https://doi.org/10.1016/j.ejsobi.2011.07.01 0

Departemen Pertanian Republik Indonesia. 2011. Peraturan Menteri Pertanian No. 70/Permentan/SR.140/10/2011 tentang Pupuk Organik, Pupuk Hayati dan Pembenah Tanah. Departemen Pertanian Republik Indonesia. Jakarta.

Doran, J.W., Sarrantonio, M., \& Liebig, M.A., 1996. Soil health and sustainability. Adv. Agron. 56, 1-54.

Ekawandani, N., \& Kusuma, A. A. (2018). Pengomposan Sampah Organik (Kubis Dan Kulit Pisang) Dengan Menggunakan Em4. 12(1), 38-43. https://doi.org/10.31227/osf.io/3gt26

Elkoca, O. (2008). A study on the characteristics of electrical discharge textured skin pass mill work roll. Surface and Coatings Technology, 202(12), 2765-2774. https://doi.org/10.1016/j.surfcoat.2007.10. 004

Green, B. W. (2015). Fertilizers in aquaculture. In Feed and Feeding Practices in Aquaculture. Elsevier Ltd. https://doi.org/10.1016/b978-0-08100506-4.00002-7

Grover, M., Ali, S. Z., Sandhya, V., Rasul, A., \& Venkateswarlu, B. (2011). Role of microorganisms in adaptation of agriculture crops to abiotic stresses. World Journal of Microbiology and Biotechnology, 27(5), 1231-1240. https://doi.org/10.1007/s11274-010-05727

Gunawan, Kusmiadi, \& Prasetiyono. (2015). Studi Pemanfaatan Sampah Organik Sayuran Sawi (Brassica juncea L.) dan Limbah Rajungan (Portunus pelagicus) Untuk Pembuatan Kompos Organik Cair. Jurnal Pertanian Dan Lingkungan, 8(1), 
37-47.

Haq, A. S., Nugroho, W. A., \& Lutfi, M. (2014). Pengaruh perbedaan sudut rak segitiga pada pengomposan sludge biogas terhadap sifat fisik dan kimia kompos. Jurnal Keteknikan Pertanian Tropis Dan Biosistem, 2(3), 225-233.

Haroun, M., Idris, A., \& Omar, S.R.S., 2007. Characterisation and composting of tannery sludge. J. Soil Sci. 11, 71-80.

Hariri, M. R., Chikmawati, T., \& Hartana, A. (2017). Genetic diversity of indigofera tinctoria L. In java and Madura islands as natural batik dye based on inter-simple sequence repeat markers. Journal of Mathematical and Fundamental Sciences, 49(2), $105-115$ https://doi.org/10.5614/j.math.fund.sci.20 17.49.2.1

Kumar S. (2020) Legumes for Carbon and Nitrogen Cycling: An Organik Approach. In: Datta R., Meena R., Pathan S., Ceccherini M. (eds) Carbon and Nitrogen Cycling in Soil. Springer, Singapore. https://doi.org/10.1007/978981-13-7264-3_10

Kurniawan, E., Ginting, Z., \& Nurjannah, P. (2017). Pemanfaatan urine kambing pada pembuatan pupuk organik cair terhadap kualitas unsur hara makro (npk). Seminar Nasional Sains Dan Teknologi, 23, 1-10. jurnal.umj.ac.id/index.php/semnastek

Kusumaningtyas, R. D., Oktafiani, O., Hartanto, D., Handayani, P. A., \& Muhammad, D. R. A. (2016). Pembuatan Pupuk OrganoMineral Fertilizer (Omf) Padat Dari Limbah Industri Bioetanol (Vinasse). 4(2), 46-54.

https://doi.org/10.15294/jbat.v4i2.4189

Laurent, C., Bravin, M. N., Crouzet, O., Pelosi, C., Tillard, E., Lecomte, P., \& Lamy, I. (2020). Increased soil $\mathrm{pH}$ and dissolved organik matter after a decade of organik fertilizer application mitigates copper and zinc availability despite contamination. Science of the Total Environment, 709. https://doi.org/10.1016/j.scitotenv.2019.13 5927

Li, J., Wen, Y., Li, X., Li, Y., Yang, X., Lin, Z., Song, Z., Cooper, J. M., \& Zhao, B. (2018). Soil labile organik carbon fractions and soil organik carbon stocks as affected by longterm organik and mineral fertilization regimes in the North China Plain. Soil and Tillage Research, 175(December 2016),
281-290.

https://doi.org/10.1016/j.still.2017.08.008

Mardwita, M., Yusmartini, E. S., Melani, A., Atikah, A., \& Ariani, D. (2019). Pembuatan Kompos Dari Sampah Organik Menjadi Pupuk Cair Dan Pupuk Padat Menggunakan Komposter. Jurnal Ilmiah Pengabdian Kepada Masyarakat, 1(2), 8083.

Moebius-Clune, B. N. (2017). Comprehensive Assessment of Soil Health, Third Edition. New York: Cornell University

Motamarri, S. M., Karthikeyan., Rajasekar, S., \& Gopal. (2012). Review paper Indigofera tinctoria Linn -A Phytopharmacological. International Journal of Research in Pharmaceutical and Biomedical Sciences, Vol 3, Issue 1.

Ney, L., Franklin, D., Mahmud, K., Cabrera, M., Hancock, D., Habteselassie, M., Newcomer, Q., \& Dahal, S. (2020). Impact of inoculation with local effective microorganisms on soil nitrogen cycling and legume productivity using composted broiler litter. Applied Soil Ecology, 154(February 2019), 103567. https://doi.org/10.1016/j.apsoil.2020.1035 67

Purnomo, E. A., Sutrisno, E., \& Sumiyati, S. (2017). Pengaruh variasi $\mathrm{c} / \mathrm{n}$ rasio terhadap produksi kompos dan kandungan kalium $(\mathrm{k})$, pospat (p) dari batang pisang dengan kombinasi kotoran sapi dalam sistem vermicomposting. Jurnal Teknik Lingkungan, $\quad 6(2)$, 1-15. https://doi.org/10.1017/CBO97811074153 24.004

Ravindran, B., Lee, S. R., Chang, S. W., Nguyen, D. D., Chung, W. J., Balasubramanian, B., Mupambwa, H. A., Arasu, M. V., AlDhabi, N. A., \& Sekaran, G. (2019). Positive effects of compost and vermicompost produced from tannery waste-animal fleshing on the growth and yield of commercial crop-tomato (Lycopersicon esculentum L.) plant. Journal of Environmental Management, 234(December 2018), 154-158. https://doi.org/10.1016/j.jenvman.2018.12 .100

Ridwan, Prasetyo S D., Kusum A A., Rahman, R.A., \& Suyitno. (2019). Recent progress of biogas produced from the waste of natural indigo dyes for electricity generation. AIP Conference 
Proceedings, 2097, 030025 (2019); https://doi.org/10.1063/1.5098200

Sánchez-Chino, X., Jiménez-Martínez, C., Dávila-Ortiz, G., Álvarez-González, I., \& Madrigal-Bujaidar, E. (2015). Nutrient and nonnutrient components of legumes, and its chemopreventive activity: A review. Nutrition and Cancer, 67(3), 401-410. https://doi.org/10.1080/01635581.2015.10 04729

Sánchez-Navarro, V., Zornoza, R., Faz, Á., \& Fernández, J. A. (2019). Comparing legumes for use in multiple cropping to enhance soil organik carbon, soil fertility, aggregates stability and vegetables yields under semi-arid conditions. Scientia Horticulturae, 246(August 2018), 835841.

https://doi.org/10.1016/j.scienta.2018.11.0 65

Sihta, F., Suyitno, Heru Wibowo, A., \& Tanding, R. (2018). Enhancing biogas quality of indigofera plant waste through codigestion with cow dung. MATEC Web of Conferences, 154. https://doi.org/10.1051/matecconf/201815 402001

Sinukaban. (1999). Sistem Pertanian Konservasi
Kunci Pembangunan Pertanian Berkelanjutan. Makalah pada Seminar Paradigma Baru Pengelolaan dan Pemanfaatan Sumberdaya Lahan yang Berkelanjutan. Medan: Universitas Sumatera Utara.

Sukaryorini, P., Masfiatul Fuad, A., \& Santoso, S. (2016). Pengaruh Macam Bahan Organik Terhadap Ketersediaan Amonium $(\mathrm{NH}+)$, C-Organik dan Populasi Mikroorganisme pada Tanah Entisol. Plumula, 5(2), 99-106. http://ejournal.upnjatim.ac.id/index.php/pl umula/article/download/760/631

Trivana, L., Yudha Pradhana, A., \& Pahala Manambangtua, A. (2017). Optimalisasi Waktu Pengomposan Pupuk Kandang Dari Kotoran Kambing Dan Debu Sabut Kelapa Dengan Bioaktivator Em4. Jurnal Sains \&Teknologi Lingkungan, 9(1), 16-24. https://doi.org/10.20885/jstl.vol9.iss1.art2

Yuniwati, M., Iskarima, F., \& Padulemba, A. (2012). Optimasi Kondisi Proses Pembuatan Kompos dari Sampah Organik dengan Cara Fermentasi Menggunakan EM4. 5(2), 172-181. 